\title{
MANAJEMEN BERBASIS SEKOLAH DALAM MENINGKATKAN MUTU PENDIDIKAN DI SMP NEGERI 02 PURWOREJO
}

\author{
Hodin \\ (SMP Negeri 15 Purworejo) \\ miftahhodin.2303@gmail.com
}

\begin{abstract}
ABSTRAK
Penelitian ini didasari oleh pentingnya manajemen berbasis sekolah dalam meningkatkan mutu pendidikan. Sehubungan dengan hal tersebut, penelitian ini bertujuan untuk mengetahui Manajemen Berbasis Sekolah dalam Meningkatkan Mutu Pendidikan di SMP Negeri 02 Purworejo. Penelitian ini merupakan penelitian kualitatif. Pengumpulan data menggunakan wawancara, observasi, dan dokumentasi, dan keabsahan data menggunakan triangulasi, dan teknik analisis data meliputi pegumpulan data, reduksi data, penyajian data, dan penarikan kesimpulan. Penelitian ini menghasilkan empat kesimpulan: (1) Otonomi sekolah dalam meningkatkan mutu pendidikan di SMP Negeri 2 Purworejo dengan Manajemen Berbasis Sekolah (MBS) sudah berjalan sesuai dengan ketentuan peraturan yang berlaku. (2) Partisipasi sekolah dalam meningkatkan mutu pendidikan yaitu sekolah selalu melibatkan komite sekolah dalam merencanakan dan menetapkan kebijakan, komite sekolah pun berperan aktif dalam membantu penyelanggaraan pendidikan di sekolah dalam kapasitasnya sebagai pemberi pertimbangan, pendukung program, pengontrol, dan bahkan mediator. (3) Kepemimpinan kepala sekolah dalam meningkatkan mutu pendidikan sangat efektif dalam mengelola sarana prasarana yang ada dan bila ada yang kurang lengkap segera berusaha melengkapi agar proses pembelajaran berjalan dengan maksimal. (4) Tim kerja sekolah melaksanakan tugas sebagai tim pengembang sekolah yaitu dengan memberikan masukan kepada sekolah sebagai bahan pertimbangan dalam mengambil keputusan, melaksanakan pembinaan untuk meningkatkan kemampuan guru, membuat perencanaan pengembangan sekolah dan membuat laporan pelaksanaan tugas.
\end{abstract}

Kata kunci: Manajemen Berbasis Sekolah dan Mutu Pendidikan.

\section{PENDAHULUAN}

Pendidikan di Indonesia pada awalnya menerapkan sistem sentralisasi yaitu melimpahkan seluruh urusan pendidikan kepada pemerintah pusat.Dalam sistem tersebut sekolah tidak diberikan wewenang yang lebih luas untukmengambil keputusan.Dengan menganut sistem sentralisasi tersebutpendidikan di Indonesia dinilai sangat kaku dan sentralistik. Hal inilah yangmenjadi hambatan dalam upaya meningkatkan kualitas pendidikan dilndonesia. "Faktor-faktor penyebab kekurangberhasilan upaya peningkatan kualitas pendidikan antara lain karena strategi pembangunan pendidikan selama ini lebih bersifat inputorienteddan pengelolaan pendidikan yang sentralistik dan macrooriented,diatur oleh jajaran birokrasi di tingkat pusat." ${ }^{19}$ Maka dari itu pemerintah berupaya untuk mengubah sistem pendidikan di Indonesia dari sentralisasimenjadi

\footnotetext{
${ }^{79}$ Sri Minarti, Manajemen Sekolah: Mengelola Lembaga Pendidikan Secara Mandiri, (Jogjakarta: Ar-Ruzz Media, 2011), hal. 48.
} 
desentralisasi di bidang pendidikan. Sistem desentralisasi di bidangpendidikan telah memberikan peluang kepada sekolah untuk meningkatkankemandirian dalam mengelola sumber daya yang dimiliki.

Kelahiran UU. No. 22 Tahun 1999, yang kemudian disempurnakan menjadi UU No. 32 Tahun 2004 tentang Pemerintah Daerah, telah mengakhiri era sentralisasi, dan kini telah lahir era desentralisasi danotonomi daerah. Satuan pendidikan sekolah yang dalam era sentralisasisering disebut sebagai sebuah institusi yang berada pada level paling bawahyang mengurus dunia pendidikan untuk anak-anak bangsa.Kini satuanpendidikan sekolah harus dapat bertanggung jawab untuk dapat mengurusdirinya sendiri, melalui mekanisme yang dikenal dengan ManajemenPendidikan Berbasis Sekolah (MBS). ${ }^{80}$

Tujuan pemerintah memberlakukan otonomi daerah di bidang pendidikan yaitu untuk menjadikan lembaga pendidikan formal dapat mandiri dalammenyelesaikan permasalahannya. Selain itu, dengan adanya otonomi daerah dibidang pendidikan pemerintah berupaya dan bertekad untuk memberdayakansekolah di seluruh jenjang pendidikan. Maka dari itu, semua urusan danwewenang diserahkan kepada pemerintah daerah kabupaten atau kota, bahkandapat diserahkan langsung kepada sekolah itu sendiri. Dalam hal ini, sekolahharus mampu memberdayakan sumber dayanya dengan meningkatkan kegiatanmanajemen sekolah yang efektif dan efisien. Namun pada kenyataannya banyak sekolah yang mengalami kendala dalammelaksanakan manajemen sekolah.Hal tersebut menjadi faktor penghambatuntuk meningkatkan mutu. Seperti yang diungkapkan Sallis yang dikutip oleh Husaini Usman, ia mengemukakan bahwa: "Sebagian besar rendahnya mutu disebabkan oleh buruknya manajemendan kebijakan pendidikan. Warga sekolah hanyalah pelaksanaan belaka darikebijakan yang telah ditetapkan atasannya.Pendapat Sallis ini mendukung pendapat Juran, salah seorang begawan mutu dunia. Juran berpendapat bahwamasalah mutu, $85 \%$ oleh manajemennya, sisanya oleh faktor lainnya." 81

Salah satu permasalahan utama rendahnya mutu pendidikan disebabkankurang terampilnya sekolah dalam mengelola manajemen sekolahnya, baik itumengelola tenaga SDM nya, kurikulum, sarana dan prasarana maupunmengelola pembiayaan pendidikan.Tanggung jawab sekolah dalam upayameningkatkan mutu pendidikan harus dimulai dari memperbaiki system manajemen sekolah. Salah satu cara untuk memperbaiki buruknya system manajemen sekolah yaitu dengan mengimplementasikan MBS (ManajemenBerbasis Sekolah).

\footnotetext{
${ }^{80}$ Suparlan Manajemen Berbasis Sekolah dari Teori sampai dengan Praktik, (Jakarta: Bumi Aksara, 2013), hal. 3.

${ }^{81}$ Husaini Usman, Manajemen: Teori, Praktik, dan Riset Pendidikan Edisi Ketiga, (Jakarta: Bumi Aksara, 2010), hal. 622-623.
} 
MBS merupakan salah satu jawaban pemberian otonomi daerah di bidang pendidikan dan telah diundang-undangkan dalam Undang-Undang Nomor 20Tahun 2003 tentang Sisdiknas Pasal 51 ayat (1) yang berbunyi: "Pengelolaan satuan pendidikan anak usia dini, pendidikan dasar, dan pendidikan menengahdilaksanakan berdasarkan standar pelayanan minimal dengan prinsipmanajemen berbasis sekolah." 82 Pergeseran dari manajemen berbasis pusat(sentralistik) menuju manajemen berbasis sekolah memerlukan peninjauankembali terhadap aturan sekolah, peran unsur-unsur sekolah, kebiasaanbertindak, dan hubungan antar unsur-unsur sekolah. Aturan sekolah perludirumuskan kembali agar sesuai dengan tuntutan manajemen berbasis sekolahyaitu otonomi, fleksibilitas, dan partisipasi. ${ }^{83}$

Manajemen Berbasis sekolah (MBS) adalah salah satu model reformasibirokrasi sebagai konsekwensi desentralisasi dalam dunia pendidikan untuk menciptakan suatu bentuk sekolah masa depan yang lebih baik dibandingkan denganyang sebelumnya. Beberapa definisi tentang MBS menegaskan bahwa konseptersebut mengacu pada manajemen sumber daya di tingkat sekolah dan bukan disuatu sistem atau tingkat yang sentralistik.Beberapa sumberdaya dalam pengertianlebih luas telah didefinisikan mencakup pengetahuan, teknologi, kekuasaan,material, manusia, waktu dan keuangan. ${ }^{84}$

Salah satu ciri terpenting dari penerapan MBS adalah bagaimana pihak sekolah mampu menyediakan layanan pendidikan yang memuaskan kepada orang tua peserta didik dan masyarakat, dan begitu pula sebaliknya sampai dimana kesiapan dan peran masyarakat dan orang tua peserta didik dalam memberikan kontribusi untuk mengembangkan dan meningkatkan sekolah/madrasah sesuai dengankebutuhan masyarakat.

Penerapan MBS di sekolah memerlukan kesiapan berbagai komponen dan perangkat stakekholder pendidikan baik secara internal maupuneksternal yang dapat mendukung pelaksanaan penerapan MBS itu sendiri antara lain:gedung sekolah yang dilengkapi dengan fasilitas sarana dan prasarana pembelajaran,kepala sekolah, pendidik dan tenaga kependidikan, peserta didik, lingkungan sekolahperan serta orang tua peserta didik, dukungan masyarakat dan dunia usaha lainnya.

Manajemen Berbasis Sekolah (MBS) merupakan salah satu wujud darireformasi pendidikan yang menawarkan kepada sekolah untuk menyediakan pendidikan yang lebih baik dan memadai bagi peserta didik. Otonomi dalam manajemen merupakan potensi

\footnotetext{
82 Ibid, hal. 623.

${ }^{83}$ Ibrahim, Implementasi Manajemen Berbasis Sekolah pada SD Negeri Sakti Pidie. (Jurnal Administrasi Pendidikan Pascasarjana Universitas Syiah Kuala, Vol. 3 Nomor 1, Tahun 2015), hal. 118.

84 Ibtisan Abu Duhou, School-Based Management (Manajemen Berbasis Sekolah), (Jakarta: Logos Wacana Ilmu, 2002), hal. 25.
} 
bagi sekolah untukmeningkatkan kinerja para staf, menawarkan partisipasi langsungkelompok-kelompok yang terkait, dan meningkatkan pemahamanmasyarakat terhadap pendidikan. ${ }^{85}$

Implementasi MBS diharapkan mampu menemukan solusi terbaik dalammengatasi permasalahan.Warga sekolah yang meliputi kepala sekolah, tenagapendidik, tenaga kependidikan harus bergerak aktif untuk mengatasi masalahyang ada di sekolah.Selain itu, partisipasi orangtua maupun masyarakat sekitarjuga harus terlibat secara aktif dalam membantu pelaksanaan manajemensekolah. Jika kegiatan manajemen sekolah berjalan dengan baik secara terusmenerus tentu akan berdampak posistif bagi warga sekolah dan jugameningkatnya mutu pendidikan di sekolah.

SMP Negeri 02 Purworejo mulaimenerapkan Manajemen Berbasis Sekolah (MBS) pada tahun 2006. Tujuan mengimplementasikan MBS tentunya untukmengembangkan sekolah atau meningkatkan mutu pendidikan berdasarkankondisi sekolah dengan mengoptimalkanya melalui kekuatan atau kelebihansekolah. Untuk meningkatkan kualitas pendidikan disuatu sekolah/madrasah harusditunjang oleh berbagai perangkat, sistem, dan strategi pengelolaannya, salah satu di antaranya adalah dengan menerapkan manajemen pendidikan. Manajemen adalah suatu proses kegiatan dan perangkat yang mengarahkan dan menuntun semua usahadan upaya suatu organisasi di dalam mencapai suatu tujuan. Seperti diketahui bahwa tugas manajemen antara lain ialah mengintegrasikan sumber-sumber pendidikan dan memanfaatkannya seoptimal mungkin. ${ }^{86}$

Manajemen Pendidikanmerupakan proses perencanaan, pengorganisasian, pengarahan dan pengawasanusaha pendidikan dalam pelaksanaan tugas pendidikan dengan mendayagunakansegala sumber secara efisien untuk mencapai tujuan secara efektif agar mencapaitujuan pendidikan yang telah ditetapkan. ${ }^{87}$

Pendidikan dapat dimaknai sebagaiproses mengubah tingkah laku peserta didik agar menjadi manusia dewasa yangmampu hidup mandiri dan sebagai anggota masyarakat dalam lingkungan alamsekitar dimana individu itu berada. ${ }^{88}$

Dengan adanya MBS, SMP Negeri 02 Purworejo ingin menciptakansuasana dan kondisi sekolah yang mandiri, transparan, akuntabel, dan memilikihubungan kerjasama yang kuat baik secara internal dan eksternal.Dalam halini, sekolah memiliki komitmen yang tinggi dalam penerapan manajemenberbasis sekolah.Kendatipun MBS telah

\footnotetext{
85 Masduki Duryat, Kepemimpinan Pendidikan: Meneguhkan Legitimasi dalam Berkontestasi di Bidang Pendidikan, (Bandung: Alfabeta, 2016), hal. 110.

${ }^{86}$ Made Pidarta, Manajemen Pendidikan Indonesia, Jakarta: Rineka Cipta, 2004), hal. 177.

${ }^{87}$ Tim Dosen Administrasi Pendidikan UPI, Manajemen Pendidikan, (Bandung: Alfabeta, 2010), hal. 87-88.

${ }^{88}$ Syaiful Sagala, Konsep dan Makna Pembelajaran, (Bandung: Alfabeta, 2010), hal. 3.
} 
diterapkan di sekolah, namun kenyataannya belumberjalan sesuai dengan yang diharapkan.Hal ini dikarenakan terdapat beberapahambatan dalam menerapkan Manajemen Berbasis Sekolah. Adapunhambatannya yakni keterbatasan waktu stakeholdersmeliputi warga sekolah,komite dan masyarakat dalam mensosialisasikan program-program sekolah.Kemudian partisipasi orang tua peserta didik dan masyarakat (komite sekolah)belum sepenuhnya berperan aktif untuk ikut dalam melaksanakan programsekolah.Kendala lainnya yakni lemahnya pemahaman warga sekolah (guru dankaryawan) dalam menerapkan prinsip-prinsip MBS yang menekankan padaaspek kemandirian, kerjasama atau kemitraan, transparansi dan akuntabilitassekolah, kemudian kurang konsistensinya tenaga pendidik dan tenagakependidikan dalam melaksanakan tupoksi, yang akan mengakibatkan kurangoptimalnya pelaksanaan kegiatan program sekolah.

Di sisi lain terdapat dampak positif dari implementasi MBS yang sudahdilaksanakan oleh sekolah yaitu banyaknya prestasi yang diraih sekolah baikdari prestasi akademik maupun non akademik. Selain itu, banyak juga lulusan-lulusan(output) yang diterima dan mampu bersaing di sekolah tingkat atasnya.

Penerapan manajemen berbasis sekolah/madrasah diperlukan kinerja dalammenata efektivitas pembelajaran yang dapat meningkatkan mutu pendidikandiharapkan berjalan sesuai dengan tujuan pendidikan, maka manajemen memegangperanan yang sangat penting dalam menata efektivitas pembelajaran secaraprofesional dengan jalan meningkatkan efektivitas para pendidik dan peserta didikdalam menjalankan proses pembelajaran yang lebih bertanggung jawab, sehinggamutu pendidikan dapat dirasakan peserta didik, begitu pula pihak pendidik dapatmeningkatkan mutu pendidikan dengan jalan meningkatkan etos kerja danprofesionalisme yang lebih baik.

Dalam rangka meningkatkan mutu pendidikan di SMP Negeri 02 Purworejodiberikan keleluasaan untuk menata proses pembelajaran dengan konsep otonomisekolah (kemandirian sekolah) yang menjamin siswa mendapatkanpelayanan pembelajaran yang bermutu dengan memperbaiki dan mengembangkankinerja kepemimpinan sekolah, mutu mengajar guru, fasilitas sekolah, program-program sekolah, dan layanan lainnya.

Sekolah diberi kewenangan untuk mengembangkan programprogramkurikulum yang sesuai dengan kebutuhan sekolah, misalnyamenambah jam mata pelajaran yang ingin ditingkatkan kadar dan mutupembelajarannya, memperkaya pokok atau subpokok bahasan dalam mata pelajarantertentu yang dianggap penting dan relevan dengan konteks kebutuhan anakdisekolah itu, memberi perhatian khusus pada pengembangan bakat danminat para peserta didik. $\mathrm{Di}$ samping itu, terbuka kemungkinan untukmengembangkan mata pelajaran yang efektif, menetapkan sumber pelajaran, fasilitasdan alat-alat pelajaran yang diperlukan. Untuk mendukung terlaksananya 
penerapan manajemen berbasis sekolah,diperlukan adanya kerja sama ( kemitraan ) dengan masyarakat melalui dewankomite sekolah dengan melibatkan semua unsur stakeholder pendidikanseperti kelompok Orang Tua, kelompok Asosiasi, kelompok Praktisi, kelompokAkademisi, kelompok pengusaha, Tokoh masyarakat dan sebagainya.

Keberadaan mereka sangat diperlukan agar berkontribusi terhadap peningkatan mutu pendidikan melalui peningkatan partisipasi. Kerja sama yang dimaksud adalah dalam bentuk kontribusi pembiayaan dan dalam bentuk kontribusi pemikiran/tenaga. Partisipasi masyarakat dalam bentuk pemikiran ikut berperan aktif dalam perencanaan,pengawasan dan pengendalian program sekolah, menyusun RAPBS sesuaidengan tuntutan dan kebutuhan masyarakat. SMP Negeri 02 Purworejo telahmemiliki gedung sekolah yang sudah memadai, lingkungan sekolah sangat kondusif,termasuk fasilitas sarana dan prasarana pendukung lainnya yakni lokasi sekolah,tenaga pendidik, peserta didik, pelaksanaan proses pembelajaran, sarana dan mediapembelajaran, tenaga administrasi, dukungan orang tua peserta didik dan masyarakat, dan sarana prasarana pendukung lainnya, dalam rangka untukmeningkatkan mutu pendidikan khususnya di SMP Negeri 02 Purworejo.

Faktor-faktor yang dapat mendukung dan menghambat dalam menerapkan manajemenberbasis pengelolaan sekolah serta cara mengatasi berbagai permasalahanyang dihadapi. Hal ini perlu ditingkatkan secara efektif dan efisien dalam rangkaoptimalisasi pemberdayaan SMP Negeri 02 Purworejo sebagaimana yang diharapkan oleh seluruh elemen masyarakat dan pemerintah.

Dengan mengimplentasikan Manajemen Berbasis Sekolah (MBS)diharapkan mampu meningkatkan mutu pendidikan melalui kemandirian daninisiatif sekolah dalam mengelola dan memberdayakan sumber daya yangtersedia, meningkatkan partisipasi warga sekolah dan masyarakat (komitesekolah), adanya hubungan kemitraan yang kuat antar stakeholders dan jugaterciptanya sekolah yang transparan dan akntabel dalam penyelenggaraanprogram sekolah.Berdasarkan latar belakang di atas, penulis tertarik untuk mengangkatpermasalahan tersebut ke dalam sebuah penelitian dengan judul "Manajemen Berbasis Sekolah dalam Meningkatkan Mutu Pendidikan di SMP N 02 Purworejo”.

\section{KAJIAN LITERATUR}

\section{Manajemen Berbasis Sekolah}

Istilah manajemen berbasis sekolah (MBS) merupakan terjemah dari "School based management". Manajemen Berbasis Sekolah merupakan sebuah program yang dicanangkan oleh pemerintah dalam upaya meningkatkan mutu pendidikan di tingkat Sekolah Dasar dan Menengah.

Pengertian Manajemen Berbasis Sekolah menurut Dirjen Dikdasmen, bahwa Manajemen Berbasis Sekolah merupakan bentuk alternatif pengelolaan sekolah dalam 
rangka desentralisasi pendidikan, yang ditandai adanya kewenangan pengambilan keputusan yang lebih luas di tingkat sekolah, partisipasi masyarakat yang relative tinggi, dalam rangka Kebijakan Pendidikan Nasional. ${ }^{89}$

Manajemen Berbasis Sekolah (MBS) yaitu model pengelolaan yang memberikan otonomi atau kemandirian kepada sekolah dan mendorong pengambilan keputusan partisipatif yang melibatkan secara langsung semua warga sekolah atau madrasah sesuai dengan standar pelayanan mutu yang ditetapkan oleh pemerintah pusat, Provinsi, Kabupaten dan Kota. ${ }^{90}$

Mulyasa juga memberikan penjelasan MBS merupakan salah satuwujud dari reformasi pendidikan yang menawarkan kepada sekolah untuk menyediakan pendidikan yang lebih baik dan memadai bagi para peserta didik. ${ }^{91}$ Otonomi dalam manajemen merupakan potensi bagi sekolah untukmeningkatkan kinerja para staf, menawarkan partisipasi langsung kelompok-kelompok yang terkait, dan meningkatkan pemahaman masyarakat terhadap pendidikan.

Dari beberapa definisi di atas dapat diambil kesimpulan bahwa MBS merupakan model pengelolaan pendidikan yang ditandai dengan otonomi sekolah untuk mengambil keputusan dengan melibatkan seluruh komponen sekolah serta pelibatan komite dan adanya respon pemerintahterhadap gejala-gejala yang muncul di masyarakat, bertujuan untukmeningkatkan efisiensi, peningkatan mutu dan pemerataan pendidikan. Peningkatan efisiensi, antara lain, diperoleh melalui keleluasaan mengelola sumber daya, partisipasi masyarakat, penyederhanaan birokrasi.Sementara peningkatan mutu dapat diperoleh, antara lain, melaluipartisipasi orang tua terhadap sekolah, fleksibilitas pengelolaan sekolahdan kelas, peningkatan profesionalisme guru dan kepala sekolah.

MBS adalah bentuk alternatif sekolah sebagai hasil daridesentralisasi dalam bidang pendidikan. Sebagai wujud dari reformasipendidikan. MBS pada prinsipnya bertumpu pada sekolah dan masyarakatserta jauh dari birokrasi yang sentralistik. MBS berpotensi meningkatkanpartisipasi masyarakat, pemerataan, efisiensi, serta menjamin yangbertumpu ditingkat sekolah. Model ini dimaksudkan untuk menjaminsemakin rendahnya control pemerintah pusat dan di pihak lain semakinmeningkatnya otonomi sekolah untuk menentukan sendiri apa yang perludiajarkan dan mengelola sumber daya yang ada untuk berinovasi.

\footnotetext{
89 Dirjen Dikdasmen, Peningkatan Mutu Pendidikan di Sekolah Dasar, (Jakarta: Departemen Pendidikan Nasional, 2001), hal. 2.

90 Departemen Agama RI, Kendali Mutu Pendidikan Agama Islam, (Jakarta: Depatemen Agama RI, 2002), hal. 2.

91 Mulyasa, E., Manajemen Berbasis Sekolah: Konsep, Strategi dan Implementasi, (Bandung: Remaja Rosdakarya, 2011), hal. 24.
} 
MBS memiliki karakter yang perlu dipahami oleh sekolah yangakan menerapkannya, karakteristik tersebut merupakan ciri khas yangdimiliki sehingga membedakan antara yang satu dengan yang lain. Menurut Bellen, dkk., Manajemen Berbasis Sekolah dapatditinjau dari 3 perspektif, yaitu penyelenggaraan sekolah, kinerja kepalasekolah, dan peran serta masyarakat. ${ }^{92}$

Karakteristik MBS bisa diketahui juga antara lain dari bagaimana sekolah dapat mengoptimalkan kinerja organisasi sekolah, proses belajar mengajar, pengelolaan sumber daya manusia, dan pengelolaan sumber daya administrasi. ${ }^{93}$

Tujuan utama Manajemen Berbasis Sekolah adalah meningkatkan efisiensi, mutu, dan pemerataan pendidikan. Peningkatan efisiensi diperoleh melalui keleluasaan mengelola sumber daya yang ada, partisipasi masyarakat, dan penyederhanaan birokrasi. Peningkatan mutu diperoleh melalui partisipasi orang tua, kelenturan pengelolaan sekolah, peningkatan profesionalisme guru, adanya hadiah dan hukuman sebagai kontrol, serta hal lain yang dapat menumbuh kembangkan suasana yang kondusif. ${ }^{94}$ Sementara itu baik berdasarkan kajian pelaksanaan di negara-negara lain, maupun yang tersurat dan tersirat dalam kebijakan pemerintah dan UU Sisdiknas No. 20 Tahun 2003, tentang Pendidikan Berbasis Masyarakat pasal 55 ayat 1: Masyarakat berhak menyelenggarakan pendidikan berbasis masyarakat pada pendidikan formal dan non formal sesuai dengan kekhasan agama, lingkungan sosial, dan budaya untukkepentingan masyarakat. Berkaitan dengan pasal tersebut setidaknya ada empat aspek tujuan MBS yaitu: kualitas (mutu) dan relevansi, keadilan, efektifitas dan efisiensi, serta akuntabilitas.

Secara teoritis dan aplikasi praksis, bahwa dalam konteks MBS, keberhasilan pendidikan harus didefinisikan ulang, bukan semata-mata pada ukuran standar prestasi siswa. Keberhasilan harus berada dalam konsep yang lebih luas, diantaranya mencakup hal sebagai berikut: pola keterampilan berpikir yang lebih baik, pemahaman dan penghargaan pada multi budaya, menurunnya tingkat putus sekolah (drop out), pelayanan kepada masyarakat, terbukanya berbagai pilihan (mata pelajaran), partisipasi di dalam kelas matematika dan IPA yang lebih tinggi, pilihan dan kesuksesan pasca pendidikan menengah, dimilikinya konsep pribadi siswa dan kreativitas serta keindahan dalam seni. Namun, apa pun kriteria keberhasilan tersebut, pencapaiannya tergantung pada kualitas program pendidikan dan pelayanan yang diberikan. Karena itu, ukuran keberhasilan implementasi MBS di Indonesia dapat dinilai setidaknya dari beberapa kriteria di bawah ini:

\footnotetext{
92 Bellen, S., dkk, Manajemen Berbasis Sekolah, Jakarta: Depdikbud, 1999), hal. 11-12.

93 Udin Syarifudin Saud, Pengembangan Profesi Guru. Bandung: Alfabeta, 2001), hal. 29.

${ }^{94}$ Mulyasa, E., Op.Cit., hal. 25.
} 
Pertama, MBS dianggap berhasil apabila jumlah siswa yang mendapat layanan pendidikan semaikin meningkat. Kedua, MBS dianggap berhasil apabila kualitas layanan pendidikan menjadi lebih baik. Ketiga,tingkat tinggal kelas menurun dan produktivitas sekolah semakin baik dalam arti rasio antara jumlah siswa yang mendaftar dengan jumlah siswa yang lulus menjadi lebih besar. Keempat, karena program-program sekolah dibuat bersama-sama dengan warga masyarakat dan tokoh masyarakat maka relevansi penyelenggaraan pendidikan semakin baik. Kelima,terjadinya keadilan dalam penyelenggaraan pendidikan karena penentuan biaya pendidikan tidak dilakukan secara pukul rata, tetapi didasarkan pada kemampuan ekonomi masing-masing keluarga. Keenam,semakin meningkatnya keterlibatan orang tua dan masyarakat dalam pengambilan keputusan di sekolah baik yang menyangkut keputusan intruksional maupun organisasional. Ketujuh, salah satu indikator penting lain kesuksesan MBS adalah semakin baiknya iklim dan budaya kerja sekolah. Kedelapan, kesejahteraan guru dan staf seolah membaik antara lain karena sumbangan pemikiran, tenaga dan dukungan dana dari masyarakatluas. Kesembilan,apabila semua kemajuan pendidikan di atas telah tercapai maka dampak selanjutnya adalah akan terjadinya demokratisasi dalam penyelenggaraan pendidikan.

\section{Mutu Pendidikan}

Berbicara tentang mutu berarti berbicara tentang sesuatu bisa berupa barang atau jasa. Barang yang bermutu adalah yang sangat bernilai bagi seseorang yang biasanya berhubungan dengan kebaikan (goodness), keindahan (beauty), kebenaran (truth), dan idealitas. Sedangkan jasa yang bermutu adalah pelayanan yang diberikan seseorang atau organisasi yang sangat memuaskan, tidak ada keluhan. ${ }^{95}$

Menurut Crosby, mutu adalah sesuai dengan yang disyaratkan atau distandarkan (conformance to requirement), yaitu sesuai dengan standar mutu yang telah ditentukan, baik inputnya, prosesnya, maupun outputnya. ${ }^{96}$ Oleh karena itu, mutupendidikan yang diselenggarakan madrasah dituntut untuk memiliki bakustandar mutu pendidikan. Mutu dalam konsep Deming adalah kesesuain dengankebutuhan pasar atau konsumen. Dalam konsepDeming, pendidikan yang bermutu adalah pendidikan yang dapatmenghasilkan pengeluaran, baik layanan dan lulusan yang sesuaikebutuhan atau harapan pelanggan (pasarnya). Sedangkan Fiegenbaummengartikan mutu kepuasan pelanggan sepenuhnya

\footnotetext{
${ }^{95}$ Engkoswara, AdministrasiPendidikan. (Bandung:Alfabeta, 2010), hal. 304.

${ }^{96}$ Hadis \& Nurhayati, Hadis \& Nurhayati, 2012, Manajemen Mutu Pendidikan, (Bandung: Alfabeta, 2012), hal. 85.
} 
(full customerssatisfaction). Suatu produk dianggap bermutu apabila dapatmemberikan kepuasan sepenuhunya kepada konsumen.

Dalam pengertian ini, maka yang dikatakan madrasah bermutu adalah madrasah yang dapat memuaskan pelangganya, baikpelanggan internal maupun eksternal.Mutu menurut Carvin, sebagaimana dikutip Nasution, adalah suatu kondisi dinamis yang berhubungan dengan produk, manusia/ tenagakerja, proses dan tugas, serta lingkungan yang memenuhi atau melebihiharapan pelanggan atau konsumen. Selera atau harapan pelangganpada suatu produk selau berubah sehingga kualitas produk harusberubah atau disesuaikan. Dengan perubahan mutu produk tersebutdiperlukan perubahan atau penigkatan-peningkatan ketrampilan tenagakerja, perubahan proses produksi dan tugas, serta perubahanlingkungan organisasi agar produk memenuhi atau melebihi harapanpelanggan. ${ }^{97}$ Gronroos menunjukkan tiga kriteria pokok dalam menilai kualitasjasa, yaitu outcome related, process related, dan image related criteria. ${ }^{98}$ Dari ketiga kriteria itu dideskripsikanenam unsur karakteristik jasa yang bermutu:

Pertama, profesionalisme dan keahlian, merupakan kriteria utama,yang membuat pelanggan percaya bahwa sumber daya manusia penyediajasa memiliki syarat profesionalisme dan keahlian yang mumpunisekaligus dapat mengha-silkan produk yang bermutu.Kedua, sikap dan perilaku yang ditunjukan personil penyedia jasadalam melayani atau melaksanakan proses sangat empatik dan siapmembantu pelanggan.

Ketiga, accessibility and flexibility, yaknisebuah proses yang dirancang secara fleksibel untuk memberikankemudahan kepada pelanggan dalam melakukan akses.Keempat, reliability and thruthworthness, yaitu reputasi yang baikdan selalu menjaga kepercayaan pelanggan menjadikan pelangganyakin dengan apa yang diberikan oleh penyedia jasa adalah sebuahpelayanan yang bermutu.

Kelima, recovery, bila terjadi kesalahan atau keluhan,pelanggan tidak akan cemas karena mereka percaya penyedia jasa dapatmenemukan pemecahan masalahnya. Keenam, reputationand credibility, yaitu kesan yang dirancang oleh penyedia jasa adalahmenjaga reputasi dan loyalitas pelanggan.Dari beberapa definisi di atas dapat diambil kesimpulan bahwapengertian mutu mengandung tiga unsur, yaitu: a) kesesuaian denganstandar, b) kesesuaian dengan harapan stakeholders, c) pemenuhan janjiyang diberikan.

Ada beberapa prinsip yang perlu dipegang dalam menerapkan program mutu pendidikan di antaranya sebagai berikut:

\footnotetext{
${ }^{97}$ Nasution, Manajemen Mutu Terpadu (Total Quality Management), (Jakarta: Ghalia Indoensia, 2001), hal. 16.

${ }^{98}$ Engkoswara, Op.Cit., hal. 305.
} 
a. Peningkatan mutu pendidikan menuntut kepemimpinan profesional dalam bidang pendidikan. Manajemen mutu pendidikan merupakan alatyang dapat digunakan oleh para profesional pendidikan dalammemperbaiki sistem pendidikan bangsa kita.

b. Kesulitan yang dihadapai para profesional pendidikan adalahketidaksmaan mereka dalam menghadapi "kegagalan sistem" yangmencegah mereka dari pengembangan atau penerapan cara atau prosesbaru untuk memperbaiki mutu pendidikan yang ada.

c. Peningkatan mutu pendidikan harus dilakukan loncat-loncatan. Normadan kepercayaan lama harus dirubah. Sekolah harus belajar bekerjsasama dengan sumbersumber yang terbatas. Para professional pendidikan harus membantu para siswa dalam mengembangkankemampuan-kemampuan yang dibutuhkan guna bersaing di duniaglobal.

d. Uang bukan kunci utama dalam usaha peningkatan mutu. Mutupendidikan dapat diperbaiki jika administrator, guru, staf, pengasa, danpimpinan kantor diknas mengembangkan sikap yang terpusat padakepemimpinan, team work, kerja sama, akuntabilitas, dan rekognisi.Uang tidak menjadi penentu dalam peningkatan mutu.

e. Kunci utama peningkatan mutu pendidikan adalah komitmen padaperubahan. Jika semua guru dan staf sekolah telah memiliki komitmenpada perubahan, pimpinan dapat dengan mudah mendorong merekamenemukan cara baru untuk memperbaiki efisiensi, produktivitas, dankualitas layanan pendidikan. Guru akan menggunakan pendekatan yangbaru atau model-model mengajar, membimbing, dan melatih dalammembantu perkembangan siswa. Demekian juga staf administrasi, iaakan menggunakan proses baru alam menyusun biaya, menyelesaikanmasalah dan mengembangkan program baru.

f. Banyak profesional di bidang pendidikan yang kurang memilikipengetahuan dan keahlian dalam menyiapkan para siswa memasukipasar kerja yang bersifat global. Ketakutan terhadap perubahan, atautakut melakukan perubahan akan mengakibatkan ketidaktahuanbagaimana mengatasi tuntutan-tuntutan baru.

g. Program peningkatan mutu dalam bidang komersial tidak dapat dipakaisecara langsung dalam pendidikan, tetapi membutuhkan penyesuaianpenyesuaiandan penyempurnaan. Budaya, lingkungan, dan proses kerjatiap organisasi berbeda. Para profesional pendidikan harus dibekali olehprogram yang khusus dirancang untuk menunjang pendidikan.

h. Salah satu komponen kunci dalam program mutu adalah system pengukuran. Dengan menggunakan sistem pengukuran memungkinkanpara profesional pendidikan dapat memperlihatkan danmendokumentasikan nilai tambah dari pelaksanaan programpeningkatan mutu pendidikan, baik terhadap siswa, orang tua maupunmasyarakat.Masyarakat dan manajemen pendidikan harus menjauhkan diri 
darikebiasaan menggunakan "program singkat", peningkatan mutu dapatdicapai melaui perubahan yang berkelanjutan tidak dengan program-program singkat. ${ }^{99}$

\section{METODE PENELITIAN}

Jenis penelitian ini yaitu kualitatif, pendekatan yang lebih menekankan pada aspek pemahaman secara mendalam terhadap suatu masalah manusia dan sosial. Waktu penelitian adalah antara 1 Januari 2019 sampai dengan 1 Juli 2019, dan tempat penelitian adalah di SMP Negeri 02 Purworejo.

Subjek dan informan penelitian ini yaitu orang-orang yang berhubungan dengan manajemen berbasis sekolah dalam meningkatkan mutu pendidikan, yaitu: kepala sekolah, wakil kepala sekolah, guru, staf, siswa, wali siswa, komite sekolah, dan alumni SMP Negeri 02 Purworejo.

Teknik pengumpulan data merupakan cara yang digunakan peneliti untuk memperoleh data penelitian yang dibutuhkan. Proses pengumpulan data dalam penelitian ini dilakukan dengan: observasi, wawancara mendalam, dan dokumentasi.

Dalam menguji keabsahan data peneliti menggunakan tehnik Triangulasi, yakni teknik pemeriksaan keabsahan data yang memanfaatkan sesuatu yang lain diluar data untuk keperluan pengecekan atau sebagai pembanding terhadap data itu.Itu artinya melakukan validasi, dengan cara mengecek dokumen program dan bukti tertulis lainnya. ${ }^{100}$ Dalam penelitian ini menggunakan Triangulasi metode yaitu menggunakan dua strategi yaitu: (1) Pengecekan terhadap derajat kepercayaan penemuan hasil penelitian dengan beberapa tehnik pengumpulan data; (2) Pengecekan derajat kepercayaan beberapa sumber data dengan metode yang sama.

Langkah-langkah yang dilakukan penulis lakukan untuk menganalisis data yang sudah diperoleh dari hasil observasi, wawancara, dan dokumentasi yaitu dengan menggunakan model analisis data Miles dan Huberman sebagaimana yang dikutip oleh Sugiyono, yaitu reduksi data (data reduction), penyajian data (data display), dan penarikan kesimpulan (conclusion drawing/verification). ${ }^{101}$

\section{HASIL PENELITIAN DAN PEMBAHASAN}

\section{Otonomi Sekolah dalam Meningkatkan Mutu Pendidikan di SMP Negeri 02 Purworejo}

Peningkatan mutu pendidikan tidak bisa dilakukan hanya dengan memperbaiki kurikulum, menambah buku pelajaran, dan menyediakan laboratorium di sekolah. Mutu pendidikan itu merupakan persoalan mikro pendidikan yang terkait dengan persoalan kemampuan guru, kesiapan sekolah dalam mendukung proses belajar dengan menyediakan

\footnotetext{
99 Nana Syaodih Sukamdinata, Pengembangan kurikulum, (Bandung: Remaja Rosdakarya, 2006), hal. 8.

100 Patton, Michael Quinn. Metode Evaluasi Kualitatif. (Yogyakarta: Pustaka Pelajar, 2006), hal. 280.

101 Sugiyono, Metode Penelitian Pendidikan, (Bandung: Alfabeta. 2009), hal. 254.
} 
fasilitas yang diperlukan, dan partisipasi masyarakat pendukung pendidikan yang ada di wilayahnya disertai penataan manajemen. ${ }^{102}$

Penyelenggaraan otonomi sekolah sebagai langkah esensial dari otonomi daerah; dan telah diterapkan suatu terobosan kebijaksanaan untuk otonomi pendidikan yang disebut manajemen berbasis sekolah (school based management). Dengan otonomi sekolah, dapat lebih dioptimalkan peran sekolah dan menghargai kebutuhan nyata di setiap sekolah. Pemerintah sekarang telah berkomitmen, bahwa pendidikan berkualitas hanya akan nyata terwujud, bila otonomi daerah berujung pada otonomi sekolah yang berbasiskan manajemen (School Based Management). ${ }^{103}$

Manajemen Berbasis Sekolah (MBS) yaitu model pengelolaanyang memberikan otonomi atau kemandirian kepada sekolah ataumadrasah dan mendorong pengambilan keputusan partisipatif yangmelibatkan secara langsung semua warga sekolah atau madrasah sesuaidengan standar pelayanan mutu yang ditetapkan oleh Pemerintah Pusat, Provinsi, Kabupaten, dan Kota. ${ }^{104}$

MBS merupakan model pengelolaan pendidikan yang ditandai denganotonomi sekolah untuk mengambil keputusan dengan melibatkan seluruhkomponen sekolah serta pelibatan komite dan adanya respon pemerintahterhadap gejala-gejala yang muncul di masyarakat, bertujuan untukmeningkatkan efisiensi, peningkatan mutu dan pemerataan pendidikan.Peningkatan efisiensi, antara lain, diperoleh melalui keleluasaanmengelola sumber daya, partisipasi masyarakat, penyederhanaan birokrasi.Sementara peningkatan mutu dapat diperoleh, antara lain, melaluipartisipasi orang tua terhadap sekolah, fleksibilitas pengelolaan sekolahdan kelas, peningkatan profesionalisme guru dan kepala sekolah.

Berdasarkan hasil penelitian yang penulis lakukan di lapangan, maka otonomi sekolah SMP N 02 Purworejo dalam meningkatkan mutu pendidikan telah mengambil kebijakan:

a. Sekolah telah dapat menyusun dan menetapkan sendiri visi, misi, strategi, tujuan, logo, lagu, dan tata tertib sekolah.

b. Sekolah memiliki kewenangan dalam penerimaan siswa baru sesuai dengan ruang kelas yang tersedia, fasilitas yang ada, jumlah guru, dan tenaga administratif yang dimiliki. Berdasarkan sumber daya pendukung yang dimilikinya, sekolah secara bertanggung jawab harus dapat menentukan sendiri jumlah siswa yang akan diterima, syarat siswa yang akan diterima, dan persyaratan lain yang terkait.

\footnotetext{
${ }^{102}$ Suryadi, Manajemen Mutu Berbasis Sekolah: Konsep dan Aplikasi, (Bandung: Sarana Panca Karya Nusa, 2002).

${ }^{103}$ Depdikbud, Konsep dan Pelaksanaan dalam Manajemen Peningkatan Mutu Berbasis Sekolah. (Jakarta: Dikmenum, 2002).

${ }^{104}$ Departemen Agama RI, Kendali Mutu Pendidikan Agama Islam, (Jakarta: Depatemen Agama RI, 2002), hal. 2.
} 
c. Sekolah telah menetapkan kegiatan intrakurikuler dan ekstrakurikuler yang akan diadakan dan dilaksanakan oleh sekolah. Dalam hal ini, dengan mempertimbangkan kepentingan daerah dan masa depan lulusannya.

d. Sekolah telah mengupayakan sarana dan prasarana pendidikan, termasuk buku pelajaran dapat diberikan kepada sekolah, dengan memperhatikan standar dan ketentuan yang ada.

e. Kepala sekolah dan guru secara bersama-sama merancang proses pengajaran dan pembelajaran yang memungkinkan peserta didik dapat belajar dengan lancar dan berhasil. Proses pembelajaran yang aktif, kreatif, efektif dan menyenangkan.

\section{Partisipasi Sekolah dalam Meningkatkan Mutu Pendidikan di SMP Negeri 02}

\section{Purworejo}

Pengelolaan sumber daya sekolah melalui partisipasi warga sekolah dan masyarakat dalam kerangka Manajemen Berbasis Sekolah diharapkan akan memberi ruang gerak yang cukup bagi sekolah untuk memberi layanan pendidikan yang bermutu sesuai dengan konteks sekolah itu sendiri. Melalui pemberian ruang gerak yang cukup, diharapkan sekolah akan muncul kreativitas, inovasi, tanggung jawab, dan upaya yang sungguhsungguh untuk mengembangkan sekolah. Konsekuensinya, maka dalam jangka panjang Manajemen Berbasis Sekolah akan mendorong timbulnya ciri-ciri khusus sekolah, sesuai dengan potensi setempat.

Di daerah yang memiliki potensi kesenian sangat mungkin akan muncul sekolah yang memiliki keunggulan di bidang kesenian. Sekolah lain mungkin akan tumbuh dengan ciri khas bidang matematika, agama, olahraga dan sebagainya. Dalam jangka panjang keunggulan yang bervariasi ini yang akan menjadi awal kebanggaan warga sekolah dan masyarakat sekitarnya. Untuk itu dalam Manajemen Berbasis Sekolah, sekolah harus diberi ruang gerak cukup dalam menjabarkan kurikulum. Dengan cara itu, setiap sekolah memiliki peluang untuk menjadi "sekolah unggul", sesuai dengan potensi yang dimiliki.Jika sekolah bersedia mengikutsertakan masyarakat (stekholder) dalam pengambilan keputusan untuk berencana, pelaksanaan dan pengendalian program berarti sekolah tersebut menggunakan manajemen partisipatif. Manajemen partisipatif akan mendorong peran serta masyarakat lebih besar terhadap sekolah.

Dewan sekolah (komite sekolah) memiliki peran: menetapkan kebijakan-kebijakan yang lebih luas, menyatukan dan memperjelas visi baik untuk pemerintah daerah dan sekolah itu sendiri, menentukan kebijakan sekolah, visi dan misi sekolah dengan mengacu kepada ketentuan nasional dan daerah, menganalisis kebijakan pendidikan, melakukan komunikasi dengan pemerintah pusat, menyatukan seluruh komponen sekolah. Pengawas sekolah berperan sebagai fasilitator antara kebijakan pemda kepada masing-masing sekolah antara lain menjelaskan tujuan akademik dan anggarannya serta memberikan bantuan teknis ketika sekolah menghadapi masalah dalam menerjemahkan visi pemda. 
Mereka memberikan kesempatan untuk mengembangkan profesionalisme staf sekolah, melakukan eksperimen metode pengajaran, dan menciptakan jalur komunikasi antara sekolah dan staf pemda.

Komite Sekolah merupakan suatu badan yang mewadahi peran serta masyarakat dalam rangka meningkatkan mutu, pemerataan dan efisiensi pengelolaan pendidikan di satuan pendidikan. Badan ini bersifat mandiri, tidak mempunyai hubungan hirarkis dengan sekolah maupun lembaga pemerintah lainnya.

Karakteristik yang paling menonjol dalam konsep MBS adalah pemberdayaan partisipasi para orangtua dan masyarakat. Sekolah memiliki fungsi subsider, fungsi primer pendidikan ada pada orangtua.

Menurut Cheng (dalam Nurkolis), ada dua bentuk pendekatan untuk mengajak orangtua dan masyarakat berpartisipasi aktif dalam pendidikan. Pertama, pendekatan school based dengan cara mengajar orangtua siswa datang kesekolah melalui pertemuan-pertemuan, konferensi, diskusi guru orangtua dan mengunjungi anaknya yang sedang belajar di sekolah. Kedua, pendekatan home based, yaitu orangtua membantu anaknya belajar dirumah dan guru berkunjung ke rumah. Sedangkan, peran masyarakat bukan hanya dukungan finansial, tetapi juga dengan menjaga dan menciptakan lingkungan sekolah yang aman dan tertib serta menjalankan kontrol sosial di sekolah. Peran tokohtokoh masyarakat dengan jalan menjadi penggerak, informan dan penghubung, koordinator dan pengusul. ${ }^{105}$

Berdasarkan hasil data yang penulis temukan di lapangan bahwa partisipasi sekolah dalam meningkatkan mutu pendidikan di SMP N 02 Purworejo sangat berperan penting. Masyarakat tersebut masuk dalam organisasi komite sekolah. SMP N 02 Purworejo dalam meningkatkan mutu pendidikan dan atau pengambilan pengambilan keputusan selalu melibatkan dan meminta peran serta komite sekolah. Hal ini karena SMP N 02 Purworejo tidak dapat melakukan peningkatan mutu tanpa adanya daya dukung dari masyarakat. Di tangan Komite Sekolah inilah menjadi jalur yang menjembatani antara keinginan dan kebutuhan pihak sekolah ke masyarakat ataupun sebaliknya. Dengan adanya komite sekolah inilah salah satu penunjang keberhasilan dalam meningkatkan mutu pendidikan.

3. Kepemimpinan Sekolah dalam Meningkatkan Mutu Pendidikan di SMP Negeri 02 Purworejo

Kepala sekolah sebagai pemimpin pendidikan merupakan orang yang paling bertanggung jawab terhadap keberhasilan pendidikan di sekolahnya. Kepala sekolah berkaitan dengan kepemimpinan dalam pelaksanaan tugas dan hubungan antar manusia. Maka syarat yang harus dipenuhi seseorang yang dipilih atau diangkat menjadi kepala

${ }^{105}$ Nurkolis, Manajemen Berbasis Sekolah Teori dan Praktek, (Jakarta: Remaja Rosdakarya, 2004). 
sekolah harus mempunyai kemampuan dalam menjalankan tugas dan kemampuan dalam membina hubungan baik dengan semua personel sekolah. Berkaitan dengan kepemimpinan kepala sekolah dalam pendidikan meliputi proses menggerakkan, mempengaruhi, memberikan motivasi dan mengarahkan orang-orang di dalam organisasi/lembaga pendidikan terutama untuk mencapai tujuan yang telah dirumuskan. Dengan demikian dapat disimpulkan bahwa seorang pemimpin pendidikan dalam hal ini adalah kepala sekolah dituntut untuk memiliki kemampuan membimbing, menggerakkan serta mendorong dan mengarahkan orang-orang yang ada dalam lembaga pendidikan, yaitu mencapai tujuan pendidikan yang telah dirumuskan sebelumnya.

Peran kepala sekolah sebagai manajer dalam meningkatkan mutu pendidikan di SMP N 02 Purworejo tidak hanya memfokuskan pada pengelolaan peserta didik saja, namun kepada seluruh pihak yang terlibat dalam kegiatan pendidikan di sekolah seperti tenaga pendidik, peserta didik, staff dan komite sekolah juga dikelola dengan sebaik-baiknya bahkan pendataan mengenai sarana prasarana sekolah pun sangat diperhatikan.

Dalam menjalankan tugasnya sebagai manajer kepala sekolah SMP N 02 Purworejo memperhatikan kualitas siswa dimana sekolah menfasilitasi siswa agar dapat belajar dengan optimal seperti tersedianya sarana prasarana pembelajaran, Untuk meningkatkan kualitas guru, kepala sekolah SMP N 02 Purworejo sering mengirim guru untuk melakukan pelatihan pembuatan media pembelajaran, seminar pembelajaran, workshop, bahkan membuat karya ilmiah. Peran Kepala Sekolah sebagai Supervisor dalam meningkatkan Mutu Pendidikan di SMP Negeri 02 Purworejo. Kepala sekolah melakukan peran supervisor dalam tiga tahapan yaitu melakukan persiapan, proses dan tindak lanjut supervisi. Pelaksanaan supervisi pembelajaran dilakukan dua kali dalam satu semester dengan teknik supervisi yang digunakan adalah observasi kelas.

\section{Kerja Tim Sekolah dalam Meningkatkan Mutu Pendidikan di SMP Negeri 02 Purworejo}

Pengetian Tim Kerja adalah kelompok yang usaha-usaha individualnya menghasilkan kinerja lebih tinggi daripada jumlah masukan individual. Hal ini memiliki pengertian bahwa kinerja yang dicapai oleh sebuah tim lebih baik daripada kinerja perindividu disuatu organsasi ataupun suatu perusahaan. Pekerja tim atau tim kerja adalah orang yang sportif, sensitif dan senang bergaul, serta mampu mengenali aliran emosi yang terpendam dalam tim dengan sangat jelas. Tim kerja menghasilkan sinergi positif melalui usaha yang terkoordinasi. Usaha-usaha individual mereka menghasilkan satu tingkat kinerja yang lebih tinggi daripada jumlah masukan individual.

Kerja tim adalah suatu kelompok yang upaya-upaya anggotanya menghasilkan kinerja yang lebih besar dari kontribusi para anggota kelompok, didalamnya ada sinergi positif yang meningkatkan kinerja dan kinerja yang dihasilkan lebih besar daripada jumlah kontribusi para anggotanya. 
Dalam sekolah yang menerapkan TQM, sekolah harus memahami akan fungsi tim yang di bentuk. Sebagai contoh adalah tim yang dibentuk untuk penyusunan mata pelajaran. Tim ini dibentuk agar memiliki fungsi penting yang mencakup:

a. Bertanggung jawab pada mutu pembelajaran

b. Bertanggung jawab pada pemanfaatan waktu para guru, material, serta ruang yang dimanfaatkan.

c. Menjadi sarana untuk mengawasi, mengevaluasi, dan meningkatkan mutu.

d. Bertindak sebagai penyalur informasi kepada pihak manajemen tentang perubahanperubahan yang diperlukan dalamproses peningkatan mutu.

\section{KESIMPULAN}

Berdasarkan analisis data dan pembahasan yang diperoleh dalam penelitian ini, maka dapat diambil kesimpulan sebagai berikut:

5. Otonomi sekolah dalam meningkatkan mutu pendidikan di SMP Negeri 2 Purworejo dengan Manajemen Berbasis Sekolah (MBS) sudah berjalan sesuai dengan ketentuan peraturan yang berlaku, sekolah telah dapat menyusun dan menetapkan sendiri visi, misi, strategi, tujuan, logo, lagu, dan tata tertib, menetapkan kegiatan intrakurikuler dan ekstrakurikuler, melengkapi sarana prasarana pendidikan dan merancang proses pembelajaran yang PAKEM.

6. Partisipasi sekolah dalam meningkatkan mutu pendidikan bahwa sekolah selalu melibatkan komite sekolah dalam merencanakan dan menetapkan kebijakan, komite sekolah pun berperanaktif dalam membantu penyelanggaraan pendidikan di sekolah dalam kapasitasnya sebagai pemberi pertimbangan, pendukung program, pengontrol, dan bahkan mediator. Untuk memajukan pendidikan di sekolah, komite sekolah membantu sekolah dalam penyelenggaraan proses belajar mengajar, manajemen sekolah, kelembagaan sekolah, sarana dan prasarana sekolah, pembiayaan pendidikan, dan mengkoordinasikan peran serta seluruh lapisan masyarakat. Kedudukannya sebagai mitra sekolah.

7. Kepemimpinan kepala sekolah dalam meningkatkan mutu pendidikan sangat efektif dalam mengelola sarana prasarana yang ada dan bila ada yang kurang lengkap segera berusaha melengkapi agar proses pembelajaran berjalan dengan maksimal. Kepala sekolah menggerakkan seluruh pihak yang terlibat dalam kegiatan pendidikan di sekolah seperti tenaga pendidik, peserta didik, staf dan komite sekolah untuk melaksanakan tugas pokok fungsinya dan peningkatan.

8. Tim kerja sekolah melaksanakan tugas sebagai tim pengembang sekolah yaitu memberikan masukan kepada sekolah sebagai bahan pertimbangan dalam mengambil keputusan, melaksanakan pembinaan untuk meningkatkan kemampuan guru, membuat perencanaan pengembangan sekolah dan membuat laporan pelaksanaan tugas.

\section{DAFTAR PUSTAKA}


Bellen, S, dkk, 1999, Manajemen Berbasis Sekolah, Jakarta: Depdikbud.

Departemen Agama RI, 2002, Kendali Mutu Pendidikan Agama Islam, Jakarta: Depatemen Agama RI.

Depdikbud, 2002, Konsep dan Pelaksanaan dalam Manajemen Peningkatan Mutu Berbasis Sekolah. Jakarta: Dikmenum.

Dirjen Dikdsamen, 2001, Peningkatan Mutu Pendidikan di Sekolah Dasar, Jakarta: Departemen Pendidikan Nasional.

Engkoswara \& AanKomariah, 2010, AdministrasiPendidikan. Bandung: Alfabeta.

Hadis \& Nurhayati, 2012, Manajemen Mutu Pendidikan, Bandung: Alfabeta.

Husaini Usman, 2010, Manajemen: Teori, Praktik, dan Riset Pendidikan Edisi Ketiga, Jakarta : Bumi Aksara.

Ibrahim, 2015, Implementasi Manajemen Berbasis Sekolah pada SD Negeri Sakti Pidie. Jurnal Administrasi Pendidikan Pascasarjana Universitas Syiah Kuala, Vol. 3 Nomor 1, hal.118.

Ibtisam Abu-Duhou, 2002, School-Based Management (Manajemen Berbasis Sekolah), Jakarta: Logos Wacana IImu.

Made Pidarta, Manajemen Pendidikan Indonesia, Jakarta: Rineka Cipta.

Masduki Duryat, 2016, Kepemimpinan Pendidikan: Meneguhkan Legitimasi dalam Berkontestasi di Bidang Pendidikan, Bandung: Alfabeta.

Mulyasa, E., 2011, Manajemen Berbasis Sekolah: Konsep, Strategi dan Implementasi, Bandung: Remaja Rosdakarya.

Nana Syaodih Sukmadinata, 2008, Pengembangan kurikulum, Bandung: Remaja Rosdakarya.

Nasution, M. N., 2001, Manajemen Mutu Terpadu (Total Quality Management), Jakarta: Ghalia Indoensia.

Nurkolis, 2004, Manajemen Berbasis Sekolah Teori dan Praktek, Jakarta: Remaja Rosdakarya.

Patton, Michael Quinn, 2006, Metode Evaluasi Kualitatif, Yogyakarta: Pustaka Pelajar.

Saud, Udin Syaefudin, 2001, Pengembangan Profesi Guru. Bandung: Alfabeta.

Sri Minarti, 2011, Manajemen Sekolah: Mengelola Lembaga Pendidikan Secara Mandiri, Jogjakarta: Ar-Ruzz Media.

Sugiyono, 2009, Metode Penelitian Pendidikan, Bandung: Alfabeta.

Suparlan, 2013, Manajemen Berbasis Sekolah dari Teori sampai dengan Praktik, Jakarta: Bumi Aksara.

Suryadi, 2002, Manajemen Mutu Berbasis Sekolah Konsep dan Aplikasi, Bandung: Sarana Panca Karya Nusa.

Syaiful Sagala, 2010, Konsep dan Makna Pembelajaran, Bandung: Alfabeta.

Tim Dosen Administrasi Pendidikan UPI, 2010, Administrasi Pendidikan, Bandung: UPI Bandung. 